\section{Widespread problem of disposal}

Boston

TIME is running out for individual states in the United States to develop facilities for disposal of low-level radioactive waste produced by nuclear reactors, industry and biomedical research and treatment. The federal Low-Level Waste Policy Act of 1980, pushed through Congress in the waning days of the Carter Administration, required the states to form regional compacts to plan and develop dumps for the low-level material generated within their borders. The deadline is January 1986, just eighteen months away.

There are at present only two sites operating, in the states of Washington and South Carolina, which take most of the low-level waste arising in the United States. After the deadline, those states will have the right to refuse waste from outside the compacts they have formed with neighbours. Political pressure has only recently forced other state governments to plan more decisively. But since the planning, public approval, development and construction of a dump will take at least five years, states outside the South Carolina and Washington compacts are unlikely to meet the deadline.

In Massachusetts a Special Legislative Commission has written a working draft of a compact that would be acceptable to the state, and is now working out guidelines for choosing potential sites.

But Massachusetts has special problems. Its strong environmental and anti-nuclear constituencies will help to ensure that the site is safe and well-contained, but a referendum proposed by activist groups and approved by state voters in 1982 will inevitably slow down the approval process. The law, known as Chapter 503, requires that once a developer has found a site, obtained all the necessary licences, performed environmental impact studies and site characterization (at a cost of at least $\$ 6$ million), both houses of the state legislature must vote that the technology and the site are superior to all others, whereupon the proposed facility must be approved by the voters in a statewide election, the next of which is in November 1986 - eleven months after the deadline.

Moreover, the other New England states have understandable doubts about whether Massachusetts could ever fulfil its part of a compact.

The potential restrictions on waste disposal after 1986 could drastically affect work that produces low-level waste unless the grace period is extended. Although the amount of waste generated has been greatly reduced (by two-thirds in the past five years in Massachusetts), some interim arrangements will have to be made. The four largest producers of radioactive waste may be able to store their own waste until a site is developed, assuming they will no longer have access to the existing sites.

Small producers, such as hospitals and universities, are hoping to avoid the huge expense of storing radioactive waste. Partly in an effort to economize, they have already made substantial reductions in their waste production, and are storing rapidly-decaying elements such as ${ }^{32} \mathrm{P}$ through fifteen or so half-lives. Any plan to build or convert a warehouse for storage is likely to face strong local opposition - and research institutions in Massachusetts are already in bad odour. Much biological waste is decomposable, making temporary storage impossible and leaving only the undesirable alternative of incineration. Although large producers such as NEN are already preparing for the possibility that they will have to store their wastes, hospitals and research institutions appear

\section{Washington}

WHILE the public health problem posed by acquired immune deficiency syndrome (AIDS) is causing growing concern, industrial companies are not losing sight of the commercial possibilities. Genetic Systems Corporation (GS), of Seattle, Washington, has formed a joint venture with Pasteur Institute Productions of Paris to develop and market a diagnostic blood test for lymphadenopathy virus (LAV), the AIDS-associated virus observed by Dr Luc Montagnier, and claims patent priority for the venture over the test developed by Dr Robert Gallo for the (probably identical) human T-cell leukaemia virus III (HTLVIII). GS has been assigned exclusive rights to market the test in the United States and Canada, while Pasteur will market the test in Europe. To complicate the issue, however, Biotech Research Laboratories, of Rockville, Maryland, plans to challenge GS's claim, saying it has an even earlier patent for a general HTLV diagnostic test that has been on sale for over a year and will now also detect HTLV-III. HTLV isolate to develop an enzyme-linked immunosorbent assay (ELISA) and filed for a general patent on the technique in the summer of 1983. The company is backed by Du Pont, one of the five selected by the federal government to produce Gallo's test (see Nature 5 July, p.6) and is contracted to undertake its manufacture. Dr Robert Ting, director of Biotech, is confident that the HTLV test he patented will cover the test for HTLV-III, even though this was discovered later. He will not use his patent rights to oppose the federal government's chosen five companies but would move swiftly against GS. The stakes are high: the world market for an AIDS blood test is put at not less than $\$ 100$ million a year.
Biotech was supplied with Gallo's first to have no strategy to fall back on.

The small producers are hoping the state will provide an interim storage facility. The Massachusetts Special Legislative Commission intends, however, to concern itself only with the long-range solution. The state government hopes the federal government will assist the process by extending the grace period and improving the laws, regulations and technology that the states must follow in creating new waste dumps.

And everyone is hoping that the states of Washington and South Carolina will cooperate and continue to allow low-level waste from other states into their dumps after the 1986 deadline. Whether they will agree is doubtful - there is strong feeling within the states that there should be no outside access. South Carolina, for example, has threatened that if Congress extends the deadline stipulated by the LowLevel Waste act, it will shut down its facility entirely.

\title{
Dispute over AIDS patent priority
}

The basis for the GS claim is that the Institut Pasteur in Paris filed for worldwide patent rights on its LAV test in September 1983, while Gallo's application, covering his high-yield permissive cell line, the uninfected cell line and the specific ELISA test for HTLV-III, was not filed until May this year. Dr Robert Nowinski of GS says it is "generally accepted that the French have priority of inventorship".

Gallo says he is "exasperated and totally fed up" with patent priority disputes. He argues that a useful blood test for HTLV. III was impossible before his discovery of the HT permissive cell line; the method for production of LAV recently described by the French group (Science 225,$63 ; 1984$ ) is, he says, nowhere near as useful. Furthermore, the tests used by the two groups are fundamentally different. By looking for antibodies to the p41 envelope protein of the virus, Gallo says he can identify AIDS patients with 100 per cent efficiency. The French group, in contrast, have not so far been able to detect this protein, and antibodies to core proteins are less well correlated with disease symptoms. Gallo says AIDS is too serious to waste time arguing about priorities: his virus and sera are freely available to any qualified recipient, and indeed reagents were supplied to the French group during their early investigations. Stocks have also been sent to Britain for use there in blood bank testing.

All parties agree that the squabble over patent priorities should not hinder the most rapid possible availability of a test. Dr Montagnier in Paris says his patent application would not be used to prevent others from producing a test; GS agrees but wants "proper allocation of commercial rights". But Gallo says of GS that "they're only in it for the money". Tim Beardsley 